\title{
Studi In Silico Senyawa Cendawan Endofit sebagai Kandidat Obat Antiangiogenesis Hemangioma
}

\section{(In Silico Study of Endophytic Fungal Compounds as Candidates for Hemangioma Antiangiogenesis Drugs)}

\author{
Masriany Masriany*, Risman Rifaldi, Eka Sukmawaty \\ (Diterima Desember 2020/Disetujui Januari 2022)
}

\begin{abstract}
ABSTRAK
Peningkatan kadar faktor angiogenesis seperti gamma interferon (Y-IF), tumor necrosis factor-beta (TNF- $\beta$ ) dan transforming growth factor-beta (TGF- $\beta$ ) diduga menjadi penyebab penyerta proses angiogenesis pada penyakit hemangioma. Cendawan endofit berpotensi dalam pencarian sumber obat baru karena cendawan mengandung senyawa antimikrob, antifungi, dan antikanker. Penelitian ini bertujuan mengevaluasi potensi dan interaksi senyawa cendawan endofit sebagai kandidat inhibitor vascular endhotelial growth factor receptor-2 (VEGFR-2) angiogenesis hemangioma serta menerapkan Lipinski's rule of five untuk membedakan molekul drug-like dari non-drug-like dan uji toksisitas secara in silico. Metode penambatan molekul menggunakan beberapa program, yaitu Autodock Vina (PyRx), PyMol, dan Discovery Studio 2019, serta menambatkan 5 ligan dari senyawa cendawan endofit Trichoderma sp. dan Aspergillus sp. dengan 2 protein target VEGFR-2 (kode protein 3VHE dan 1Y6A). Ligan yang memiliki afinitas pengikatan terbaik diuji dengan Lipinski's rule of five dan uji toksisitas dengan Toxtree. Hasilnya menunjukkan bahwa benzil benzoat berpotensi sebagai antiangiogenesis yang menghambat protein VEGFR-2 berdasarkan nilai afinitas pengikatan yang mendekati nilai ligan kontrol sebesar -8,7 kkal/mol (3VHE) dan $-7,4 \mathrm{kkal} / \mathrm{mol}$ (1Y6A). Dengan demikian, benzil benzoat, kloromisetin, dan 1-heksil-3-nitrobenzena memenuhi aturan Lipinski. Berdasarkan hasil uji toksisitas dan parameter Kroes TTC decision tree, benzil benzoat dan kloromisetin termasuk kategori senyawa yang aman dikonsumsi.
\end{abstract}

Kata kunci: angiogenesis, benzil benzoate, cendawan endofit, molecular docking, VEGFR-2

\section{ABSTRACT}

Increasing levels of angiogenic factors such as gamma interferon (Y-IF), tumor necrosis factor-beta (TNF- $\beta$ ), and transforming growth factor-beta (TGF- $\beta$ ) are thought to be the cause of the angiogenesis process in hemangiomas. Endophytic fungi are potential in searching for new drug sources due to their antimicrobial, antifungal, and anticancer compounds. This study aimed to determine the potential and interactions of endophytic fungi as candidates for vascular endothelial growth factor receptor-2 (VEGFR-2) angiogenesis hemangiomas and apply Lipinski's rule of five to differentiate drug-like and non-drug-like molecules and in-line toxicity using in silico test. The research method was molecular docking using several programs, namely Autodock Vina (PyRx), PyMol, and Discovery Studio 2019, and tethering five ligands from the endophytic fungus Trichoderma sp. and Aspergillus sp. with 2 VEGFR-2 target proteins (protein codes were $3 \mathrm{VHE}$ and $1 \mathrm{Y} 6 \mathrm{~A}$ ). The best binding affinity of the ligands was tested by Lipinski's rule of five and toxicity test using Toxtree. The results showed that benzyl benzoate is potentially an antiangiogenesis inhibitor for VEGFR-2 protein based on its binding affinity value, which is close to the control ligand value of -8.7 $\mathrm{kcal} / \mathrm{mol}(3 \mathrm{VHE})$ and $-7.4 \mathrm{kcal} / \mathrm{mol}$ (1Y6A). Therefore, benzyl benzoate, chloromycetin, and 1-hexyl-3-nitrobenzene compounds comply with Lipinski's rule of five. Based on the results of the toxicity test and the parameters of the Kroes TTC decision tree, benzyl benzoate and chloromycetin are categorized as safe compounds for consumption.

Keywords: angiogenesis, benzyl benzoate, endophytic fungi, molecular docking, VEGFR-2

\section{PENDAHULUAN}

Menurut riset kesehatan dasar Kementerian Kesehatan RI (2007) tumor digolongkan ke dalam penyakit tidak menular yang berbahaya, dengan jumlah kematian tertinggi nomor tujuh di Indonesia

Program Studi Biologi, Fakultas Sains dan Teknologi, Universitas Islam Negeri Alauddin Makassar, Jl. Sultan Alauddin No.63, Romangpolong, Gowa 92113

* Penulis Korespondensi:

Email: masriany.musa@uin-alauddin.ac.id dengan persentase $5,7 \%$ dari keseluruhan jumlah penduduk Indonesia. Berdasarkan data riset kesehatan, setiap 1000 orang terdapat 4 orang pengidap tumor. Angka kematian akibat penyakit tumor terus meningkat setiap tahun. Menurut WHO, dalam kurun waktu 10 tahun diperkirakan jumlah kematian akibat tumor rata-rata 8,4 juta/tahun dan yang tertinggi terjadi pada tahun 2015, yakni mencapai 9 juta jiwa.

Tumor merupakan jaringan baru (neoplasma) yang timbul dalam tubuh akibat berbagai faktor internal dan 
eksternal. Faktor internal di antaranya mutasi gen, kelainan vaskuler, dan kelainan hormonal, sedangkan faktor eksternal yang paling umum adalah radikal bebas, obat-obatan, dan pola hidup tidak sehat. Tumor dibagi menjadi tumor jinak dan tumor ganas. Proses proliferasi dari tumor jinak relatif terbatas, dan hanya tumbuh dan berekspansi pada daerah yang sempit/lokal, dan laju pertumbuhannya relatif lambat. Sebaliknya, tumor ganas tumbuh pesat, bersifat invasif, dan bermetastasis. Tumor ganas inilah yang disebut dengan kanker (Desen 2008).

Hemangioma adalah salah satu kelainan vaskuler berupa tumor jinak, tipe angiogenesis murni, ditandai dengan meningkatnya faktor-faktor dari angiogenesis seperti sel-sel endotel yang mengalami hiperplasia serta faktor supresi sel yang berkurang sebagaimana pertama kali diklasifikasikan oleh Mulliken dan Glowacki pada tahun 1982. Hemangioma menunjukkan proliferasi endotel yang meningkat pada tahun pertama kelahiran, kemudian mengalami involusi dan regresi spontan pada usia 6-7 tahun. Sementara itu, malformasi vaskuler terdiri atas pembuluh displastik dengan siklus endotel yang normal. Malformasi vaskuler tidak selalu tampak saat lahir, bersifat meluas dan mengembang, tidak pernah mengalami involusi dan regresi (Sudjatmiko 2010).

Proses angiogenesis berperan penting pada terbentuknya hemangioma. Angiogenesis atau neovaskularisasi merupakan suatu proses pembentukan pembuluh darah baru yang terjadi secara normal dan sangat penting dalam proses pertumbuhan dan perkembangan maupun patogenesis. Perkembangan sel-sel kanker yang abnormal memungkinkan sel-sel tersebut mendapatkan suplai nutrisi dan oksigen dalam proses proliferasi dan diketahui menjadi kunci utama dari neovaskularisasi (Giavazzi et al. 2000).

Peptida-peptida angiogenik seperti basic fibroblast growth factor (bFGF) dan vascular endothelial growth factor (VEGF) telah terbukti berkait erat dengan proses pembentukan pembuluh darah baru (Boon et al. 2011). Meningkatnya kadar faktor-faktor angiogenesis dan berkurangnya kadar inhibitor angiogenesis seperti gamma interferon (Y-IF), tumor necrosis factor-beta (TNF- $\beta$ ), dan transforming growth factor-beta (TGF- $\beta$ ) menjadi penyebab penyerta proses tersebut (Breugem et al. 2001).

Cendawan endofit sangat bermanfaat dalam penemuan sumber obat alami yang baru. Hal ini dimungkinkan karena cendawan mudah dikembangbiakkan, mempunyai siklus hidup yang relatif pendek, dan mampu memproduksi berbagai senyawa bioaktif dengan jumlah yang relatif banyak dalam waktu singkat (Adriani 2015). Beberapa cendawan endofit telah menunjukkan keragaman metabolit sekunder yang cukup tinggi, termasuk untuk menghasilkan komponen kimia khas dalam inangnya (Agusta 2009). Mikrob endofit hidup bersama inangnya bersimbiosis dan memproduksi metabolit sekunder yang mempunyai aktivitas antikanker antifungi, dan antimikrob (Kumala \& Pratiwi 2014).

Pemanfaatan media komputasi dalam menemukan obat yang cepat, murah, dan ramah lingkungan belakangan ini menjadi pilihan yang baik dan signifikan. Komputasi mempunyai standarisasi/ kemampuan yang kian meningkat secara teratur dan merupakan suatu peluang besar dalam pengembangan simulasi dan kalkulasi untuk mendesain obat. Metode in silico telah menemukan momentum yang nyata pada kimia komputasi dalam pemodelan molekul (desain obat) terbaru (Geldenhuys 2006).

Penelitian ini bertujuan untuk mengukur kemampuan dan interaksi senyawa cendawan endofit sebagai kandidat penghambat vascular endhotelial growth factor receptor-2 (VEGFR-2) angiogenesis hemangioma serta menerapkan Lipinski's rule of five untuk membedakan molekul drug-like dan non druglike, serta uji toksisitasnya secara in silico.

\section{METODE PENELITIAN}

\section{Alat dan Bahan}

Alat yang digunakan dalam penelitian ini adalah seperangkat komputer pribadi (PC/Laptop) Toshiba RV409 lengkap dengan sistem operasi dan aplikasi pendukung. Sistem operasi yang digunakan adalah Windows 8 Pro 64-bit, dan aplikasi pendukung yang digunakan adalah Microsoft Office 2013, AutoDockTools 4.2, AutoDock Vina, DS Visualizer, Pubchem, swissAdme, AdmeTsar, RSCB-PDB, Way2Drug, BIOVIA, PyRx, PyMol, Python, dan Open Babel.

Bahan yang digunakan untuk uji in silico adalah 2 protein VEGFR-2 dalam bentuk berkas (file) dengan kode protein 3VHE (Gambar 1) dan 1Y6A (Gambar 2) yang diunduh dari situs resmi protein data bank (www.rcsb.org), 22 senyawa marker cendawan endofit (12 senyawa aktif Trichoderma sp. dan 10 senyawa aktif Aspergillus sp.), dan senyawa dari ligan asli (native ligand) dalam bentuk berkas (file) untuk pembanding.

\section{Preparasi Ligan Trichoderma sp. dan Aspergillus sp.}

Ligan uji pada penelitian ini didapatkan dari senyawa cendawan endofit hasil GC-MS penelitian sebelumnya dengan rincian 4 senyawa cendawan Trichoderma sp. (benzil benzoat, kloromisetin, asam oleat, dan asam 1,2-benzenadikarboksilat), serta 1 senyawa Aspergillus sp. (1-heksil-3-nitrobenzena). Pada kelima ligan uji (Gambar 3) ini telah dilakukan data mining dengan aplikasi Way2Drug, SwissAdme, dan AdmeTsar untuk mendapatkan data lebih lanjut terkait kegunaan senyawa dan informasi penting lainnya sehingga 22 senyawa marker cendawan endofit telah diseleksi secara komputasi. Proses preparasi dilakukan dengan mengunduh berkas ligan pada situs www.PubChem.org. Ialu dipreparasi pada 
aplikasi PyRx dengan program Open Babel untuk meminimumkan ligan sebelum ditambat. Berkas ligan disimpan dalam bentuk " $p d b$ ". Untuk proses penambatan, ligan uji diprogram dengan "AutoDock Ligand" dan berkas berubah dalam bentuk "pdbqt".

\section{Preparasi Reseptor VEGFR-2}

Berkas protein target yang telah diunduh kemudian dipreparasi peranti lunak DS Visualizer, yang merupakan tahap pertama dalam penambatan molekul. Pada umumnya didapatkan banyak molekul dengan susunan residu yang sama pada berkas protein, sehingga beberapa molekul yang terdapat

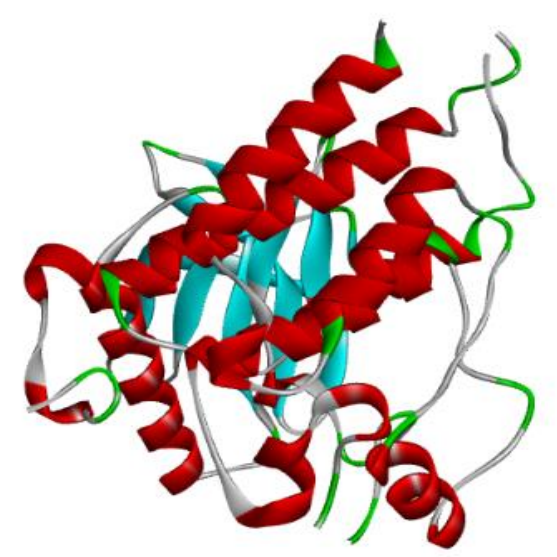

Gambar 1 Protein VEGFR2 (Kode 3VHE).

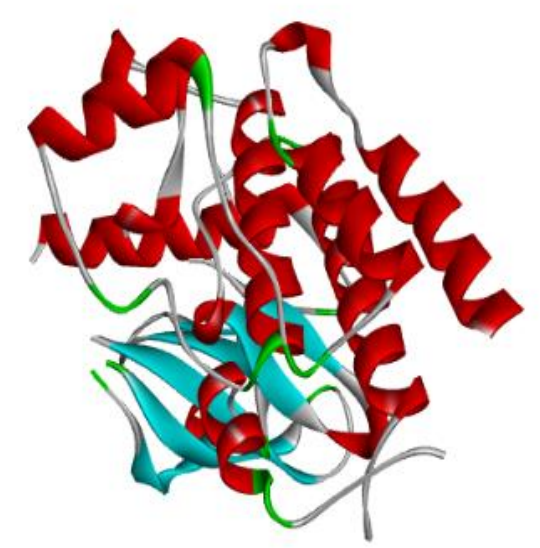

Gambar 2 Protein VEGFR2 (Kode 1Y6A). pada berkas protein perlu untuk dihapus dan diambil satu molekul saja. Komponen residu yang merupakan jenis residu pengganggu (senyawa air dan senyawa detergen) dan senyawa ligan asli dihilangkan/dihapus dari berkas, dengan tujuan menghindari kemungkinan ligan uji melekat pada molekul pengganggu. Berkas protein yang telah dipreparasi disimpan dalam bentuk "pdb" sesuai dengan nama kode protein, yaitu "3VHE.pdb" dan "1 Y6A.pdb". Senyawa ligan asli (Tabel 1) pada protein target diunduh dalam situs www.PubChem.org. dan dipreparasi dalam aplikasi PyRx dengan program minimisasi sehingga mudah untuk ditambatkan dan disimpan dalam bentuk "Ligan asli.pdb". Untuk proses pada saat penambatan, berkas "Ligan asli.pdb" diubah dalam bentuk "Ligan asli.pdbqt" sehingga proses penambatan dapat berlangsung.

\section{Penambatan Ligan Uji pada Reseptor}

Berkas ligan dan protein yang diperoleh kemudian disimpan dalam satu folder, setelah itu dijalankan penambatan molekuler dengan peranti lunak AutoDock Vina. Peranti lunak ini dirancang untuk menambat protein dan ligan sesuai target perlekatan. AutoDock Vina juga dipakai untuk mengamati skor energi ikatan dari ligan yang diuji dengan protein target.

\section{Visualisasi dan Analisis Hasil Penambatan}

Setelah skor afinitas pengikatan dengan kode " 1 " dari beberapa ligan yang diuji dan nilai RMSD $<2,00 \AA$ ditemukan, hasil tersebut disimpan dalam bentuk berkas " $s d f$ " dan " $c s V$ " dan kemudian divisualisasi dengan mengoperasikan peranti lunak DS Visualizer dan PyMOL. Rancangan ini memperlihatkan suasana interaksi dan mengubah struktur molekul, sekuen, data refleksi sinar $\mathrm{X}$, dan data lainnya jika diperlukan. Peranti lunak ini dapat dioperasikan dalam sistem operasi Windows dan Linux.

\section{Penapisan Keserupaan Obat Berdasarkan Ligan (Pindai Obat)}

Cendawan endofit yang memiliki energi bebas lebih rendah dari ligan uji lainnya diamati sebagai kandidat penghambat angiogenesis. Drug-like dan non-drug-like diamati dan dianalisis dengan mempertimbangkan aturan Lipinski's rule of five.
Benzil Benzoat

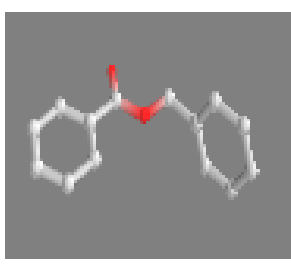

1-Heksil-3 Nitrobenzena

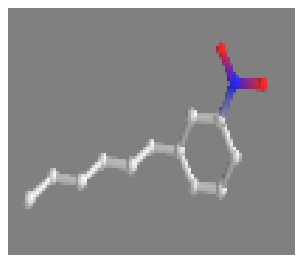

Kloromisetin

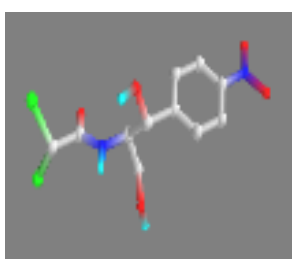

Asam Oleat

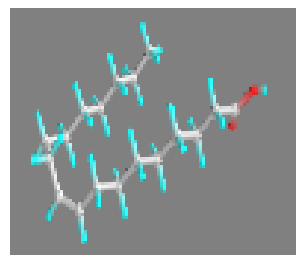

Asam 1,2benzenadikarboksilat

Gambar 3 Struktur ligan uji.

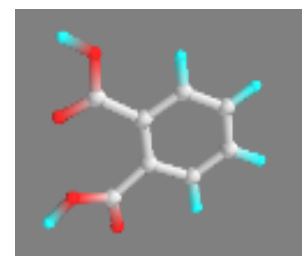




\section{Uji Toksisitas dengan Toxtree}

Toksisitas diuji terhadap senyawa cendawan endofit yang memiliki energi bebas lebih rendah dari ligan uji lainnya menggunakan peranti lunak ToxTree. Parameter yang dilihat adalah prediksi parameter Cramer Rules, Benigni/Bossa rulebase, dan Kroes TTC decision tree (Tambunan et al. 2012; Patlewicz et al. 2008; Contrera 2013; Bhatarai et al. 2016; Bhatia et al. 2015).

\section{HASIL DAN PEMBAHASAN}

Berikut ini merupakan struktur protein VEGFR-2 beserta ligan asli yang dimilikinya, ligan uji, hasil penambatan, dan visualisasi.

\section{Visualisasi dan Analisis Hasil Penambatan}

Proses penambatan ligan uji dari cendawan endofit serta ligan asli pada protein target VEGFR-2 menghasilkan nilai afinitas pengikatan seperti yang tertera pada Tabel 2. Untuk protein 3VHE ialah benzil benzoat sebesar -8,7 kkl/mol; 1-heksil-3-nitrobenzena $-7,7 \mathrm{kkl} / \mathrm{mol}$; kloromisetin $-7,4 \mathrm{kkl} / \mathrm{mol}$; asam oleat $-7,1$ $\mathrm{kkl} / \mathrm{mol}$; dan asam 1,2-benzenadikarboksilat $-6,5$ $\mathrm{kkl} / \mathrm{mol}$. Hasil penambatan ligan uji dan ligan asli pada protein (1Y6A) ialah benzil benzoat sebesar $-7,4$ $\mathrm{kkl} / \mathrm{mol}$; 1-heksil-3-nitrobenzena $\quad-6,7 \quad \mathrm{kkl} / \mathrm{mol}$; kloromisetin $-6,0 \mathrm{kkl} / \mathrm{mol}$; asam oleat $-5,8 \mathrm{kkl} / \mathrm{mol}$; dan asam 1,2-benzenadikarboksilat $-5,2 \mathrm{kkl} / \mathrm{mol}$. Dengan demikian, diketahui bahwa ikatan ligan asli dengan reseptor VEGFR-2 lebih kuat jika dibandingkan dengan ligan uji senyawa penanda (marker) cendawan endofit.
Dari hasil penambatan, urutan senyawa dengan skor terbaik untuk kedua protein adalah sebagai berikut: ligan asli $>$ benzil benzoat $>1$-heksil-3-nitrobenzena $>$ kloromisetin > asam oleat > asam 1,2benzenadikarboksilat. Hasil ini telah menunjukkan bahwa ligan asli (Gambar 4 dan 6) menggambarkan ikatan yang lebih stabil dan optimum dengan protein VEGFR-2 jika dibandingkan beberapa ligan uji, dan senyawa penanda cendawan endofit benzil benzoat (Trichoderma sp.) mempunyai energi ikatan yang baik dan stabil daripada beberapa ligan uji lainnya serta mampu dan lebih bermanfaat sebagai antiangiogenesis. Benzil benzoat sebagai ligan uji senyawa penanda dari cendawan Trichoderma sp. yang memiliki nilai energi pengikatan terbaik dengan skor $-8,7 \mathrm{kkl} / \mathrm{mol}$ (3VHE) dan $-7,4 \mathrm{kkl} / \mathrm{mol}$ (1Y6A), dan nilai RMSD <2.00. Susanti et al. (2021) menyatakan bahwa benzil benzoat dan kloromisetin memiliki energi afinitas pengikatan sekitar $-7,0$ sampai $-7,6 \mathrm{kkal} / \mathrm{mol}$ dengan reseptor dermatitis seboroik, dan berdasarkan beberapa uji in silico kedua senyawa tersebut memenuhi syarat sebagai kandidat obat dermatitis seboroik. Rachmania et al. (2016) berpendapat bahwa afinitas pengikatan merupakan skor energi yang dibutuhkan ligan untuk melekat ke reseptor atau protein target pada tapak pengikatan. Sebaliknya, menurut Brooijmans (2009) RMSD ialah nilai yang digunakan untuk menentukan dan memprediksi modus ikatan tersebut dan sangat penting dalam memvalidasi program penambatan. Nilai RMSD $<2,00 \AA ̊$ merupakan nilai yang baik. Semakin besar penyimpangan, semakin besar juga galat pada prediksi interaksi senyawa ligan dengan target protein.

Tabel 1 Ligan asli

\begin{tabular}{ccc}
\hline Nama & Ligan \\
\cline { 2 - 4 } Struktur Ligan asli 3VHE & Ligan asli 1Y6A \\
\hline
\end{tabular}

Tabel 2 Nilai energi pengikatan

\begin{tabular}{lccc}
\hline \multicolumn{1}{c}{ Ligan } & Reseptor target & $\begin{array}{c}\text { Energi pengikatan } \\
(\mathrm{kkal} / \mathrm{mol})\end{array}$ & Nilai RMSD \\
\hline Ligan kontrol 3VHE & 3VHE & $-11,9$ & $<2,00 \AA$ \\
Benzil benzoat & 3VHE & $-8,7$ & $<2,00 \AA$ \\
1-Heksil-3-nitrobenzena & 3VHE & $-7,7$ & $<2.00 \AA$ \\
Kloromisetin & 3VHE & $-7,4$ & $<2,00 \AA$ \\
Asam oleat & 3VHE & $-7,1$ & $<2,00 \AA$ \\
Asam 1,2-benzenadikarboksilat & 3VHE & $-6,5$ & $<2.00 \AA$ \\
Ligan kontrol 1Y6A & $1 \mathrm{Y} 6 \mathrm{~A}$ & $-8,4$ & $<2,00 \AA$ \\
Benzil benzoat & $1 \mathrm{Y} 6 \mathrm{~A}$ & $-7,4$ & $<2,00 \AA$ \\
1-Heksil-3-nitrobenzena & $1 \mathrm{Y} 6 \mathrm{~A}$ & $-6,7$ & $<2,00 \AA$ \\
Kloromisetin & $1 \mathrm{Y} 6 \mathrm{~A}$ & $-6,0$ & $<2,00 \AA$ \\
Asam oleat & $1 \mathrm{Y} 6 \mathrm{~A}$ & $-5,8$ & $<2,00 \AA$ \\
Asam 1,2-benzenadikarboksilat & $1 \mathrm{Y} 6 \mathrm{~A}$ & $-5,2$ & $<2,00 \AA$ \\
\hline
\end{tabular}


Hasil visualisasi (Gambar 5) menunjukkan bahwa senyawa uji tersebut mempunyai 8 ikatan yang berinteraksi dengan residu asam amino pada protein 3VHE, yaitu valina pada posisi 848 (VAL848); alanina pada posisi 866 (ALA866); leusina pada posisi 840 (LEU840); leusina pada posisi 1035 (LEU1035); valina pada posisi 899 (VAL899); valine pada posisi 916 (VAL916); sisteina pada posisi 1045 (CYS1045); dan lisina pada posisi 868 (LYS868). Pada protein 1Y6A (Gambar 7), senyawa uji benzil benzoat mempunyai 6 ikatan yang berinteraksi dengan residu asam amino, yaitu valina pada posisi 914 (VAL914); leusina pada posisi 1033 (LEU1033); valine pada posisi 897 (VAL897); alanina pada posisi 864 (ALA864); valina

(a)

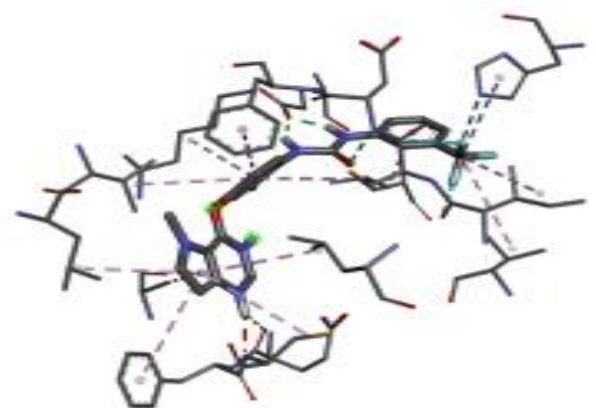

pada posisi 846 (VAL846); dan lisina pada posisi 866 (LYS866).

Hasil visualisasi menunjukkan bahwa senyawa uji benzil benzoat dan ligan asli protein 3VHE melekat pada 6 residu yang sama, yaitu VAL848, ALA866, LEU840, LEU1035, CYS1045, dan LYS868. Senyawa uji benzil benzoat melekat pada ligan asli protein 1 Y $6 \mathrm{~A}$ pada 4 residu yang sama, yaitu VAL914, LEU1033, VAL846, dan LYS866. Perlu diamati juga interaksi yang terjadi antara senyawa ligan dan residu-residu protein target; interaksi yang terjadi berupa ikatan hidrogen, interaksi hidrofobik, dan interaksi elektrostatik (Arwansyah 2014). Identifikasi tersebut menggunakan perangkat lunak PyMol untuk

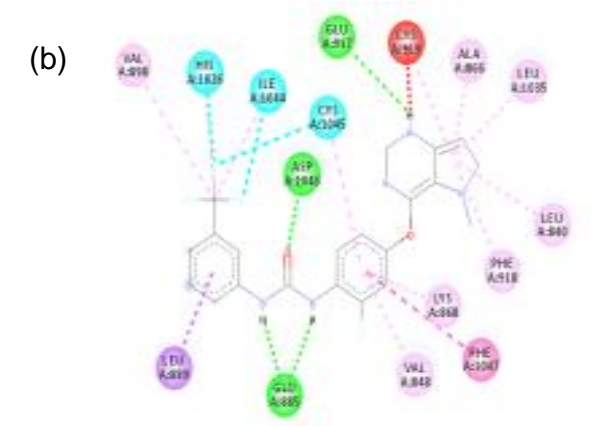

Gambar 4 (a) Hasil penambatan 1-\{2-fluoro-4-[(5-metil-5H-pirrolo[3,2 d]pirimidin-4-il)oks]fenil\}-3-[3-(trifluorometil)fenil]urea sebagai ligan kontrol. (b) Ikatan ligan dengan residu protein.

(a)

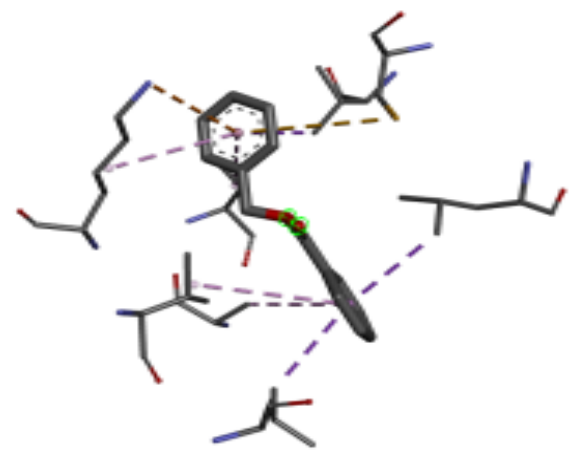

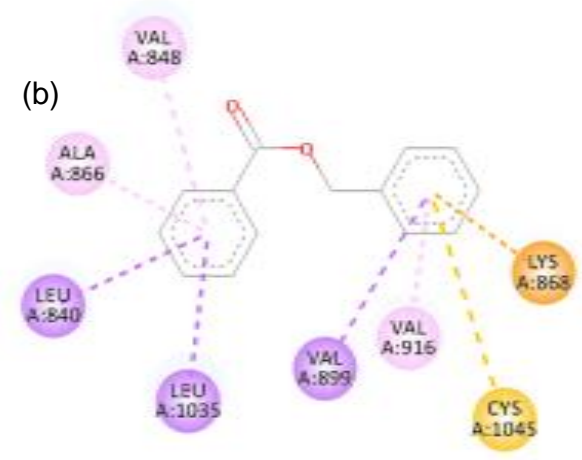

Gambar 5 (a) Hasil penambatan benzil benzoat sebagai ligan uji. (b) Ikatan ligan dengan residu asam amino.

(a)

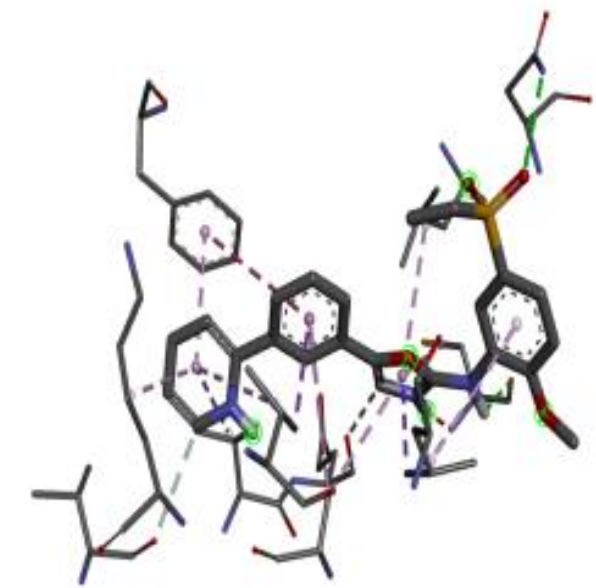

(b)

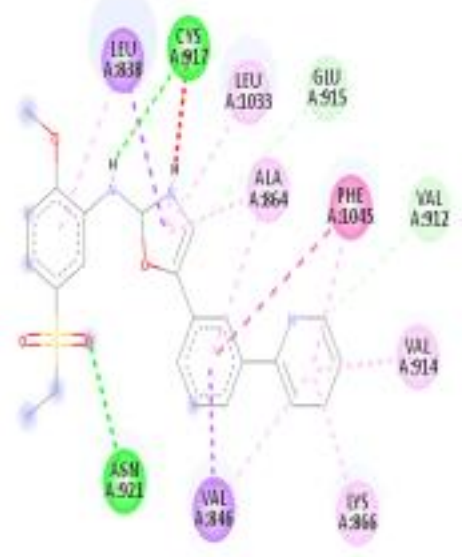

Gambar 6 (a) Hasil penambatan N-[5-(etiklsulfonil)-2-metoksifenil]5-[3-(2-piridinil)fenil]-1,3-oksazol-2-amina sebagai ligan kontrol. (b) Ikatan ligan dengan residu asam amino. 
(a)

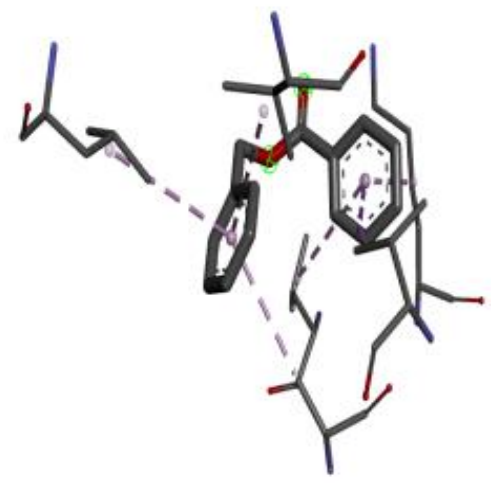

(b)

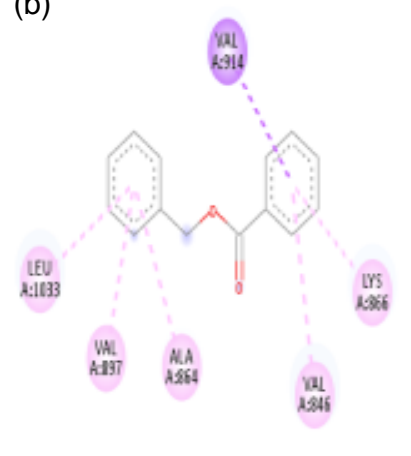

Gambar 7 (a) Hasil penambatan benzil benzoat sebagai ligan uji. (b) Ikatan ligan dengan residu protein.

mengamati kesamaan dari segi bentuk dan volume antara ligan dan target protein. Ikatan yang terjadi antara benzil benzoat dan protein 3VHE terdiri atas 6 ikatan hidrofobik (VAL848, ALA866, LEU840, LEU1035, VAL899, VAL916), 1 katan elektrostatik (LYS868), dan 1 ikatan sulfida (CYS1045). Adapun untuk benzil benzoat dan protein 1Y6A terdapat 6 ikatan hidrofobik tanpa ada interaksi lain. Ikatan benzil benzoat dengan kedua protein tidak memperlihatkan keberadaan ikatan hidrogen. Senyawa ligan yang mempunyai jenis ikatan hidrogen lebih dari 1 tidak menjamin ikatan stabil dan optimum. Hal ini karena nilai afinitas pengikatan yang diperoleh dari ligan yang memiliki ikatan hidrogen $>1$ tidak menyamai atau mendekati nilai ligan asli. Tidak hanya karena interaksi antara ikatan hidrogen dan nilai afinitas pengikatan, terdapat banyak faktor yang memengaruhi kestabilan dan optimumnya suatu ikatan. Benzil benzoat yang tidak mempunyai jenis ikatan hidogen memiliki lebih banyak interaksi ikatan lain yang dominan, di antaranya interaksi hidrofobik dan interaksi elektrostatik yang berkontribusi pada nilai skor afinitas pengikatan selain ikatan hidrogen. Hal ini sejalan dengan pernyataan Schneider et al. (2008) bahwa residu ionik menyumbang lebih besar dalam penentuan skor afinitas pengikatan, dan diikuti oleh residu polar, aromatik, hidrofobik secara berurutan.

\section{Penerapan Aturan Lipinski}

Sifat fisikokimia ligan dan karakter hidrofobik/ hidrofilik suatu senyawa melalui membran sel oleh difusi pasif dapat ditentukan dengan menerapkan aturan Lipinski. Nilai log $P$ menunjukkan nilai koefisien dari kelarutan di dalam lemak/air yang memiliki nilai antara -0,4-5. Bobot molekul yang lebih dari $500 \mathrm{~g} / \mathrm{mol}$ tidak akan berdifusi melewati membran sel. Semakin besar nilai $\log P$, semakin hidrofobik molekul tersebut. Senyawa yang mempunyai sifat hidrofobik akan memiliki tingkat toksisitas yang juga tinggi karena akan terkurung lebih lama pada bagian lipid dua-lapis (bilayer) dan tersebar lebih luas di dalam tubuh sehingga tingkat selektivitas ikatan terhadap enzim target menjadi berkurang. Nilai log $P$ yang terlalu negatif juga tidak baik sebab senyawa tersebut tidak bisa menembus membran lipid dua-lapis dengan baik. Jumlah donor dan akseptor ikatan hidrogen menggambarkan bahwa semakin tinggi kapasitas ikatan hidrogen, semakin tinggi energi yang dibutuhkan agar proses penyerapan dapat terjadi. Secara umum aturan Lipinski menggambarkan permeabilitas senyawa tertentu untuk menembus membran sel secara difusi pasif (Syahputra et al. 2014).

Berdasarkan nilai afinitas pengikatan dari penambatan molekul didapatkan tiga senyawa yang memiliki nilai afinitas terendah dibandingkan ligan uji lainnya, yaitu benzil benzoat, 1-heksil-3-nitrobenzena, dan kloromisetin. Ketiga senyawa tersebut selanjutnya dianalisis dengan memperhatikan beberapa aturan.

Berdasarkan hasil uji Lipinski's Rule of Five ketiga senyawa uji (Tabel 3) dengan afinitas pengikatan terendah tersebut memenuhi kaidah Lipinski. Benzil benzoat memiliki bobot molekul 212, gugus hidrogen donor 0 , gugus hidrogen akseptor $2, \log P 3,043599$, dan refraktivitas molar 62,003487. Ciri ligan 1-heksil-3nitrobenzena ialah bobot molekul 207, gugus hidrogen donor 0 , gugus hidrogen akseptor $2, \log P 3,717599$ dan refraktivitas molar 60,942387. Senyawa kloromisetin mempunyai bobot molekul 323, gugus hidrogen donor 3 , gugus hidrogen akseptor 6 , log $P$ $-0,102320$, dan refraktivitas molar 67,048691. Dengan demikian, kemungkinan ketiga ligan tersebut aktif secara klinik bila diberikan secara oral karena penyerapannya yang baik. Hal ini sejalan dengan dengan pernyataan Choy et al. (2011) bahwa senyawa dikatakan memiliki absorpsi dan permeabilitas tinggi apabila memenuhi dua atau lebih aturan Lipinski.

\section{Prediksi Toksisitas}

Hasil uji toksisitas dengan mengoperasikan peranti lunak Toxtree pada senyawa cendawan endofit yang memiliki energi lebih rendah dari ligan uji lainnya tertera pada Tabel 4. Menurut parameter aturan Cramer, benzil benzoat termasuk ke dalam kategori satu, yaitu toksisitas rendah (low class) dan kloromisetin termasuk ke dalam kategori tiga, yakni toksisitas tinggi (high class). Hal ini memperlihatkan bahwa kloromisetin termasuk dalam senyawa dengan 
Tabel 3 Hasil Lipinski's Rule of Five senyawa uji

\begin{tabular}{lcccccc}
\hline \multicolumn{1}{c}{ Molekul } & Rumus & $\begin{array}{c}\text { Bobot } \\
\text { molekul }\end{array}$ & $\begin{array}{c}\text { Akseptor } \\
\text { ikatan-H }\end{array}$ & $\begin{array}{c}\text { Donor } \\
\text { ikatan-H }\end{array}$ & $\begin{array}{c}\text { Log } P \\
\text { Refraktivitas } \\
\text { molar }\end{array}$ \\
\hline $\begin{array}{l}\text { Benzil benzoat } \\
\text { 1-Heksil-3- }\end{array}$ & $\mathrm{C}_{6} \mathrm{H}_{5} \mathrm{CH}_{2} \mathrm{O}_{2} \mathrm{C}_{6} \mathrm{H}_{5}$ & 212 & 2 & 0 & 3,043599 & 62,003487 \\
nitrobenzena & $\mathrm{C}_{12} \mathrm{H}_{17} \mathrm{NO}_{2}$ & 207 & 2 & 0 & 3,717599 & 60,942387 \\
Kloromisetin & $\mathrm{C}_{11} \mathrm{H}_{12} \mathrm{Cl}_{2} \mathrm{~N}_{2} \mathrm{O}_{5}$ & 323 & 6 & 3 & $-0,102320$ & 67,048691 \\
\hline
\end{tabular}

Tabel 4 Hasil uji toksisitas dengan Toxtree

\begin{tabular}{lccc}
\hline \multicolumn{1}{c}{ Ligan } & Benzil benzoat & 1-Heksil-3-Nitrobenzena & \multicolumn{1}{c}{ Kloromisetin } \\
\hline Substituen & $\mathrm{C}_{6} \mathrm{H}_{5} \mathrm{CH}_{2} \mathrm{O}_{2} \mathrm{C}_{6} \mathrm{H}_{5}$ & $\mathrm{C}_{12} \mathrm{H}_{17} \mathrm{NO}_{2}$ & $\mathrm{C}_{11} \mathrm{H}_{12} \mathrm{Cl}_{2} \mathrm{~N}_{2} \mathrm{O}_{5}$ \\
Cramer Rules & 1 & 0 & 3 \\
$\begin{array}{l}\text { Benigni/Bosa } \\
\text { Rulebase }\end{array}$ & 8.9 & 0 & 1.9 \\
Kroes TTC Decision & 1 & 0 & 2
\end{tabular}

Keterangan: Cramer rules = 1 rendah (Class I), 3 tinggi (Class III), Benigni/Bosa rulebase = 1 (struktur diwaspadai sebaga karsinogenisitas genotoksik); 8 (negatif untuk karsinogenisitas genotoksik); 9 (negatif untuk karsinogenisitas non-genotoksik). Kroes TTC decision tree $=1$ (Zat tidak diperkirakan aman); 2 (risiko dapat diiabaikan; probabilitas rendah untuk risiko kanker seumur hidup lebih besar dari 1 dalam $10^{6}$ ).

struktur kimia yang dianggap tidak terjamin keamanannya, atau memungkinkan terjadi toksisitas yang signifikan, atau mempunyai gugus fungsi yang reaktif dibandingkan benzil benzoat yang toksisitasnya rendah. Menurut parameter aturan Benigni/Bossa, benzil benzoat tidak bersifat karsinogenik sedangkan kloromisetin bersifat karsinogenik tinggi. Namun, risiko mutagenisitas tidak ditunjukkan oleh parameter ini. Selain itu, menurut parameter Kroes TTC decision tree, benzil benzoat termasuk kategori 1, yaitu senyawa diduga tidak aman dan berisiko bagi kesehatan, sedangkan kloromisetin termasuk kategori 2, yakni bahwa risiko toksisitas dari senyawa dapat diabaikan. Adapun senyawa 1-heksil-3-nitrobenzena tidak terdeteksi pada peranti lunak Toxtree.

\section{KESIMPULAN}

Berdasarkan hasil penambatan dapat disimpulkan bahwa senyawa benzil benzoat dari cendawan Trichoderma sp. mampu berinteraksi dengan baik pada protein VEGFR-2 dengan nilai afinitas pengikatan dengan protein $3 \mathrm{VHE}$ dan dengan protein $1 \mathrm{Y} 6 \mathrm{~A}$ masing-masing adalah $-8,7 \mathrm{kkl} / \mathrm{mol}$ dan $-7,4 \mathrm{kkl} / \mathrm{mol}$. Berdasarkan analisis Lipinski, tiga senyawa yang diuji memenuhi persyaratan klinis sebagai obat oral, dan untuk uji toksisitas senyawa benzil benzoat termasuk kategori dengan toksisitas rendah dibandingkan 2 senyawa lainnya.

\section{DAFTAR PUSTAKA}

Agusta. 2015. 2009. Biologi dan kimia jamur Endofit. Bandung (ID): ITB Press.

Adriani. 2015. Prosising Seminar Nasional Mikrobiologi Kesehatan dan Lingungan. Aktiifitas Antibakterial fungi Endofit Coulerpa Racemosa Terhadap Bakteri
Escherichia coli dan Staphylococcus aureus. Makassar, 29th Januari 2015.

Bhatia S, Schultz T, Roberts D, Shen J, Kromidas L, Marie AA. 2015. Comparison of cramer classification between toxtree, the OECD QSAR toolbox and expert judgment. Regulatory Toxicology and Pharmacology journal. 71(1): 5262. https://doi.org/10.1016/j.yrtph.2014.11.005

Bhhatarai B, Wilson DM, Parks AK, Carney EW, Spencer PJ. 2016. Evaluation of TOPKAT, toxtree, and derek nexus in silico models for ocular irritation and development of a knowledge-based framework to improve the prediction of severe irritation. Chemical Research in Toxicology journal. 29(2): 413-418. https://doi.org/10.1021/acs.chemrestox $.5 \mathrm{~b} 00531$

Boon LM, Ballieux F, Vikkula M. 2011. "Pathogenesis of vascular anomalies. Clinics in Plastic Surgery. 38(1): 7-19. https://doi.org/10.1016/j.cps.2010. 08.012

Breugem CC, van Der Horst CM, Hennekam RC. 2001. Progress toward understanding vascular malformations. Plastic and Reconstructive Surgery. 107(6): 1509-1523. https://doi.org/10.1097/00 006534-200105000-00033

Choy Y, Bin, Prausnitz MR. 2011. The rule of five for non-oral routes of drug delivery: ophthalmic, inhalation, and transdermal. Pharmaceutical Research. 28(5): 943-948. https://doi.org/ $10.1007 / \mathrm{s} 11095-010-0292-6$

Contrera JF. 2013. Validation of toxtree and SciQSAR in silico predictive software using a publicly available benchmark mutagenicity database and their applicability for the qualification of impurities in pharmaceuticals. Regulatory Toxicology and Pharmacology. 67(2): 285-293. https://doi.org/ 10.1016/j.yrtph.2013.08.008 
Desen. 2008. Buku Ajar Onkologi Medik. edisi 2. Jakarta (ID): Balai penerbit FKUI.

Geldenhuys WJ, Gaasch KE, Watson M, Allen DD, Van der Schyf Cornelis J. 2006. Optimizing the use of open-source software applications in drug discovery. Drug Discovery Today. 11(3-4): 127-132. https://doi.org/10.1016/S1359-6446 (05)03692-5

Giavazzi R, Albini A, Bussolino F, DeBraud F, Presta M, Ziche M, Costa A. 2012. The biological basis for antiangiogenic therapy. European Journal of Cancer. 36(15): 1913-1918. https://doi.org/ 10.1016/S0959-8049(00)00276-8

Kumala S, Pratiwi AP. 2014. Efek antimikroba dari kapang endofit ranting tanaman biduri. Jurnal Farmasi Indonesia. 7(2): 111-120.

Mulliken JB, Glowacki J. 1982. Hemangioma and vascular malformations in infants and children: $A$ classification based on endothelial characteristic. Plastic Reconstructive Surgery. 69(3): 412-422. https://doi.org/10.1097/00006534-19820300000002
Patlewicz G, Jeliazkova N, Safford RJ, Worth AP, Aleksiev B. 2008. An evaluation of the implementation of the Cramer classification scheme in the Toxtree software. SAR and QSAR in Environmental Research. 19(5-6): 495-524. https://doi.org/10.1080/10629360802083871

[Riskesdas] Riset Kesehatan Dasar. 2007. Badan Litbangkes, Depkes RI. Jakarta (ID).

Sudjatmiko G. 2010. Hemangioma. In: Petunjuk praktis ilmu bedah plastik rekonstruksi edisi 2. Jakarta (ID): Yayasan khazanah kebajikan.

Susanti S, Sukmawaty E, Masriany. 2021. Penambatan Molekuler Senyawa Cendawan Endofit Trichoderma sp. Sebagai Inhibitor Protein Lower Density Lipoprotein, Enzim Lanasterol 4A Demetilase dan Lipase yang Bertanggung Jawab dalam Dermatitis Seboroik. Jurnal IImiah Ibnu Sina. 6(1): 98-107. https://doi.org/10.36387/jiis. v6i1.636

Tambunan USF, Amri N, Parikesit AA. 2012. In silico design of cyclic peptide as influenza virus, a subtype $\mathrm{H} 1 \mathrm{~N} 1$ neuraminidase inhibitor. African Journal of Biotechnology. 11(52): 11474-11491. https://doi.org/10.5897/AJB11.4094 